\title{
Widespread movement of meltwater onto and across Antarctic ice shelves
}

\author{
Jonathan Kingslake ${ }^{1}$, Jeremy C. Ely ${ }^{2}$, Indrani Das ${ }^{1} \&$ Robin E. Bell ${ }^{1}$
}

Surface meltwater drains across ice sheets, forming melt ponds that can trigger ice-shelf collapse $e^{1,2}$, acceleration of grounded ice flow and increased sea-level rise $\mathrm{r}^{3-5}$. Numerical models of the Antarctic Ice Sheet that incorporate meltwater's impact on ice shelves, but ignore the movement of water across the ice surface, predict a metre of global sea-level rise this century ${ }^{5}$ in response to atmospheric warming ${ }^{6}$. To understand the impact of water moving across the ice surface a broad quantification of surface meltwater and its drainage is needed. Yet, despite extensive research in Greenland ${ }^{7-10}$ and observations of individual drainage systems in Antarctica ${ }^{10-17}$, we have little understanding of Antarctic-wide surface hydrology or how it will evolve. Here we show widespread drainage of meltwater across the surface of the ice sheet through surface streams and ponds (hereafter 'surface drainage') as far south as $85^{\circ} \mathrm{S}$ and as high as 1,300 metres above sea level. Our findings are based on satellite imagery from 1973 onwards and aerial photography from 1947 onwards. Surface drainage has persisted for decades, transporting water up to 120 kilometres from grounded ice onto and across ice shelves, feeding vast melt ponds up to 80 kilometres long. Largescale surface drainage could deliver water to areas of ice shelves vulnerable to collapse, as melt rates increase this century. While Antarctic surface melt ponds are relatively well documented on some ice shelves, we have discovered that ponds often form part of widespread, large-scale surface drainage systems. In a warming climate, enhanced surface drainage could accelerate future ice-mass loss from Antarctic, potentially via positive feedbacks between the extent of exposed rock, melting and thinning of the ice sheet.

We conducted the first Antarctic-wide survey of visible satellite imagery aimed at constraining the locations and glaciological settings occupied by surface drainage systems between 1947 and

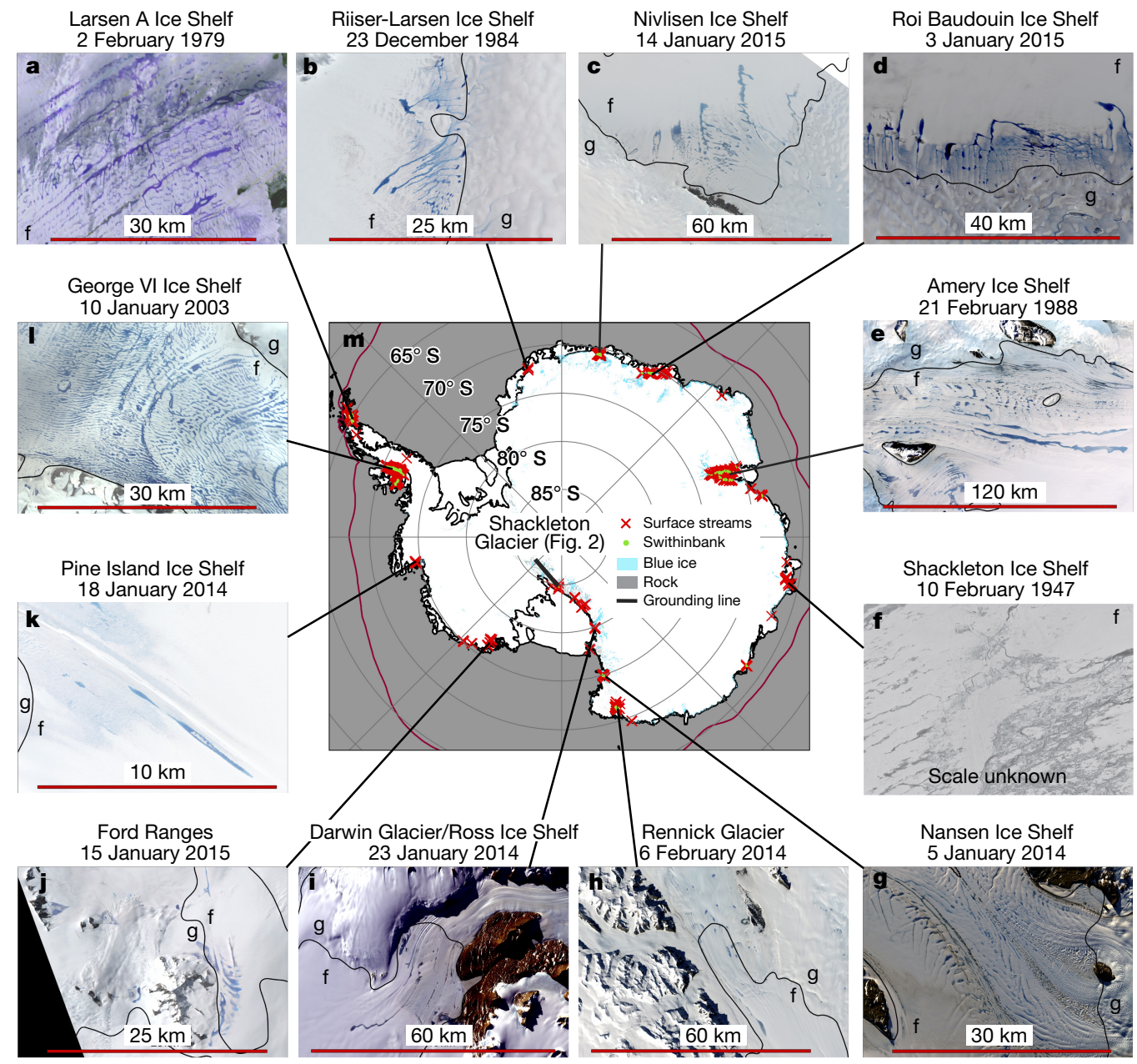

Figure 1 | Surface meltwater drainage around Antarctica. a-l, Surface drainage systems mapped in this study (red crosses in centre panel $\mathbf{m}$ ) and locations found by an early survey ${ }^{14}$ (green dots). All lie within the $0^{\circ} \mathrm{C}$ contour of modelled mean January air temperature (red curve; Methods). Panels a-l show examples of surface drainage systems consisting of streams and ponds (1947-2015) (Extended Data Table 1). In all panels, narrow meandering structures are identified as streams (Methods). The grounding line $e^{28}$ (black) is the boundary between grounded and floating ice. ' $\mathrm{f}$ ' and 'g' in the panels distinguish floating and grounded ice. See Extended Data Table 1 for details of imagery. Source Data for this figure are available in the online version of the paper. 
2015 (Methods). These systems typically consist of meltwater ponds connected by surface streams. We identified several hundred (696) such systems on ice shelves and major outlet glaciers distributed around the continent. We restrict our focus here to systems that display evidence for water moving across the surface through streams and ponds, while recognizing that other drainage processes, such as flow through snow or surface sheet flow, could also contribute to the movement of surface water.

Large-scale surface drainage onto and across the Pine Island, Sulzberger, Riiser-Larsen and Shackleton ice shelves, and on several glaciers in the Trans-Antarctic Mountains is previously unreported (Fig. 1). We also identified evidence for surface drainage on the Larsen, Nansen, Nivlisen, Roi Baudouin, George VI and Amery (Fig. 1) ice shelves, where surface streams have been observed ${ }^{13-15,18-21}$.

Surface streams exist at latitudes from $64.0^{\circ} \mathrm{S}$ on the Antarctic Peninsula to $85.2^{\circ} \mathrm{S}$ on Shackleton Glacier (Figs 1 and 2) and elevations from near sea level to more than 1,300 $\mathrm{m}$ above sea level (Figs 2, 3 and $4 \mathrm{a}$ ). Around two-thirds of streams identified originate on ice flowing more slowly than $120 \mathrm{~m} \mathrm{yr}^{-1}$ and many are found adjacent to lowalbedo areas such as exposed rock that protrudes through the ice sheet (nunataks) and 'blue ice' (Fig. 4b) ${ }^{11}$. Many streams transport water from areas of the ice sheet undergoing surface ablation, into areas that are covered in snow (which is potentially permeable to meltwater; Fig. 1).
Within $600 \mathrm{~km}$ of the South Pole, on Shackleton Glacier (Figs 1 and 2) water is transported up to $70 \mathrm{~km}$ from the edge of the East Antarctic Plateau (1,350 $\mathrm{m}$ above sea level) onto the Ross Ice Shelf ( $85 \mathrm{~m}$ above sea level; Fig. 2; Extended Data Fig. 1). Meltwater is produced at high elevations near rock at the glacier margin and flows through streams (Extended Data Fig. 1), marginal melt ponds (Fig. 2f) and many closely spaced ponds on Swithinbank Moraine (Extended Data Fig. 1). At lower elevations water drains through streams running parallel to surface lineations (Fig. 2e, i). At less than $200 \mathrm{~m}$ above sea level streams coalesce to form a braided network that crosses the grounding line (Fig. 2j) and feeds a pond on the Ross Ice Shelf (Fig. 2k; Extended Data Fig. 1a). Other glaciers in the Trans-Antarctic Mountains that support surface drainage systems include the Darwin, Nimrod, Lennox-King and Liv glaciers.

In many systems meltwater originates in ablation areas on the icesheet's flanks and flows long distances across ice shelves. For example, on Amery Ice Shelf a complex network of interconnected streams transports water up to $120 \mathrm{~km}$, feeding vast ice-shelf melt ponds, up to $3.5 \mathrm{~km}$ wide and $80 \mathrm{~km}$ long (Fig. 3 and Extended Data Fig. 2). During December 2014 and January 2015, the largest pond on the ice shelf grew to $56.7 \pm 1.2 \mathrm{~km}^{2}$ in area over 25 days and its downstream margin migrated at up to $3,670 \pm 20 \mathrm{~m}$ per day (Fig. $3 \mathrm{~b}$, c; Extended Data Fig. 2). This drainage-fed mode of pond formation-involving
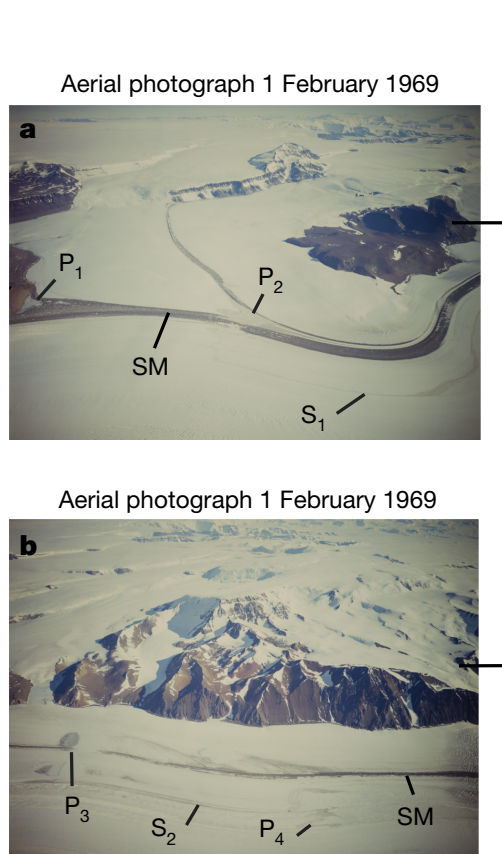

Aerial reconnaissance photo 12 January 2010

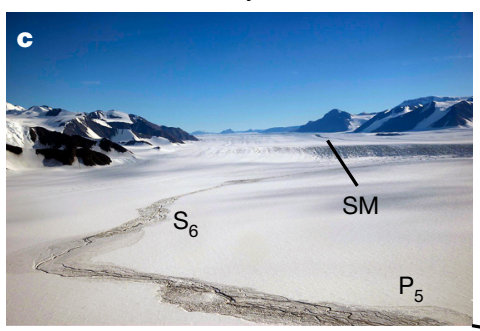

d

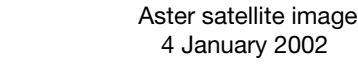

\section{西}

4 January 2002

\section{西}


a

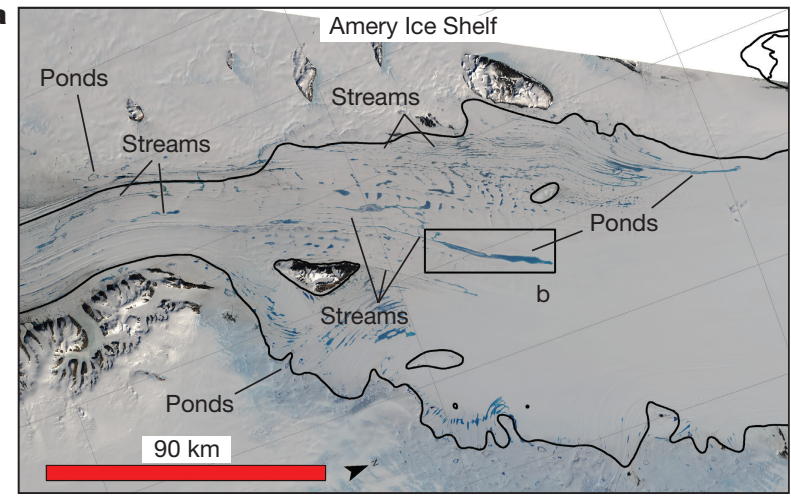

b

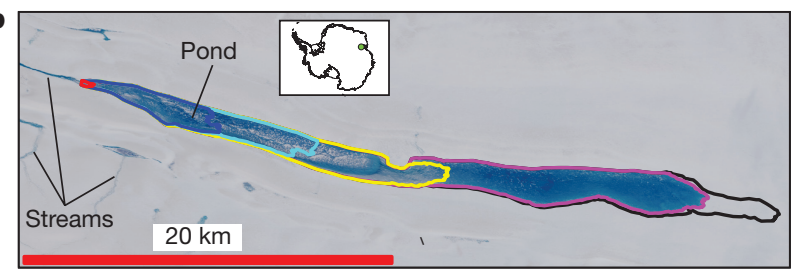

- 28 December 2014 - 6 January 2015

- 30 December 2014 - 15 January 2015

- 31 December 2014 - 22 January 2015

c

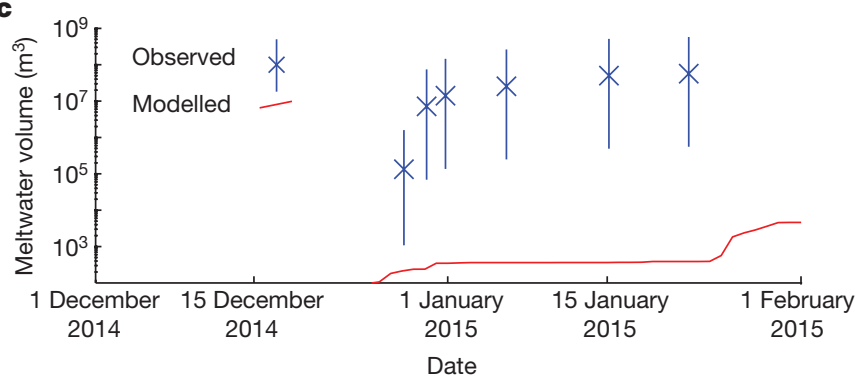

the accumulation of meltwater from a large catchment via surface drainage-contrasts with in situ ponding of meltwater observed elsewhere in Antarctica ${ }^{22}$. Drainage-fed ponds on ice shelves are
Figure 3 Drainage onto and across Amery Ice Shelf. a, LANDSAT 8 image from 22 January 2015 showing complex stream networks, barely resolvable at the scale of the image, feeding large meltwater ponds. $\mathbf{b}$, The largest pond observed. It has formed here regularly since at least 1974 (Extended Data Figs 2 and 4). The pond margins are mapped in colour by date (Methods). c, Time series of meltwater volume in the pond estimated from imagery assuming $1 \mathrm{~m}$ deep water (crosses). Error bars are computed assuming a depth of between $1 \mathrm{~cm}$ and $10 \mathrm{~m}$. Melt water production across the entire ice shelf was modelled using RACMO2 (https://www.projects. science.uu.nl/iceclimate/models/racmo.php) (red) (Methods). Source Data for this figure are available in the online version of the paper.

common (Fig. 1), for example on Pine Island Ice Shelf (Extended Data Fig. 3).

Antarctic surface meltwater drainage has persisted for decades (Extended Data Fig. 4 and Extended Data Table 2). On Shackleton Glacier, melt features appear in aerial photography from 1960 onwards (Fig. 2; Extended Data Figs 1 and 4) and in satellite imagery in 2002 and 2010 (Fig. 2d-k). Near Roi Baudouin Ice Shelf, aerial photography from 1947 reveals ponds and streams at the grounding line that have persisted for 68 years (Extended Data Fig. 5). Water has regularly drained onto and across Nivlisen ${ }^{14,15}$, George VI ${ }^{14,21}$, Riiser-Larsen (Extended Data Fig. 6), Amery ${ }^{13,14}$, Pine Island (Extended Data Fig. 3) and Ross (Extended Data Fig. 7) ice shelves over the last 40 years (Extended Data Fig. 4; Extended Data Table 2).

Surface albedo is a key control on surface melt in Antarctica ${ }^{17}$. Lowalbedo blue ice ${ }^{11,23}$, nunataks and surface debris facilitate melting by increasing the absorption of solar energ $\mathrm{y}^{24}$. Blue ice forms when snow is entirely removed by wind erosion ${ }^{25}$, sublimation or melt, often adjacent to nunataks ${ }^{26}$, because rugged terrain promotes high winds and low-albedo rock increases air temperatures ${ }^{27}$. Melting and wind erosion lower the ice surface, enlarging areas of exposed rock, leading to coupling between melting, rock exposure and blue-ice formation.

We found a close spatial association between drainage, blue ice and exposed rock: despite blue ice and exposed rock together occupying only $2.2 \%$ of the continent's area, $50 \%$ of drainage systems originate within $3.6 \mathrm{~km}$ of blue ice and $50 \%$ originate within $8 \mathrm{~km}$ of exposed rock (Fig. $4 \mathrm{~b}$ ). Further south than $75^{\circ} \mathrm{S}$ this association is stronger (Extended Data Fig. 8), probably because lower air temperatures
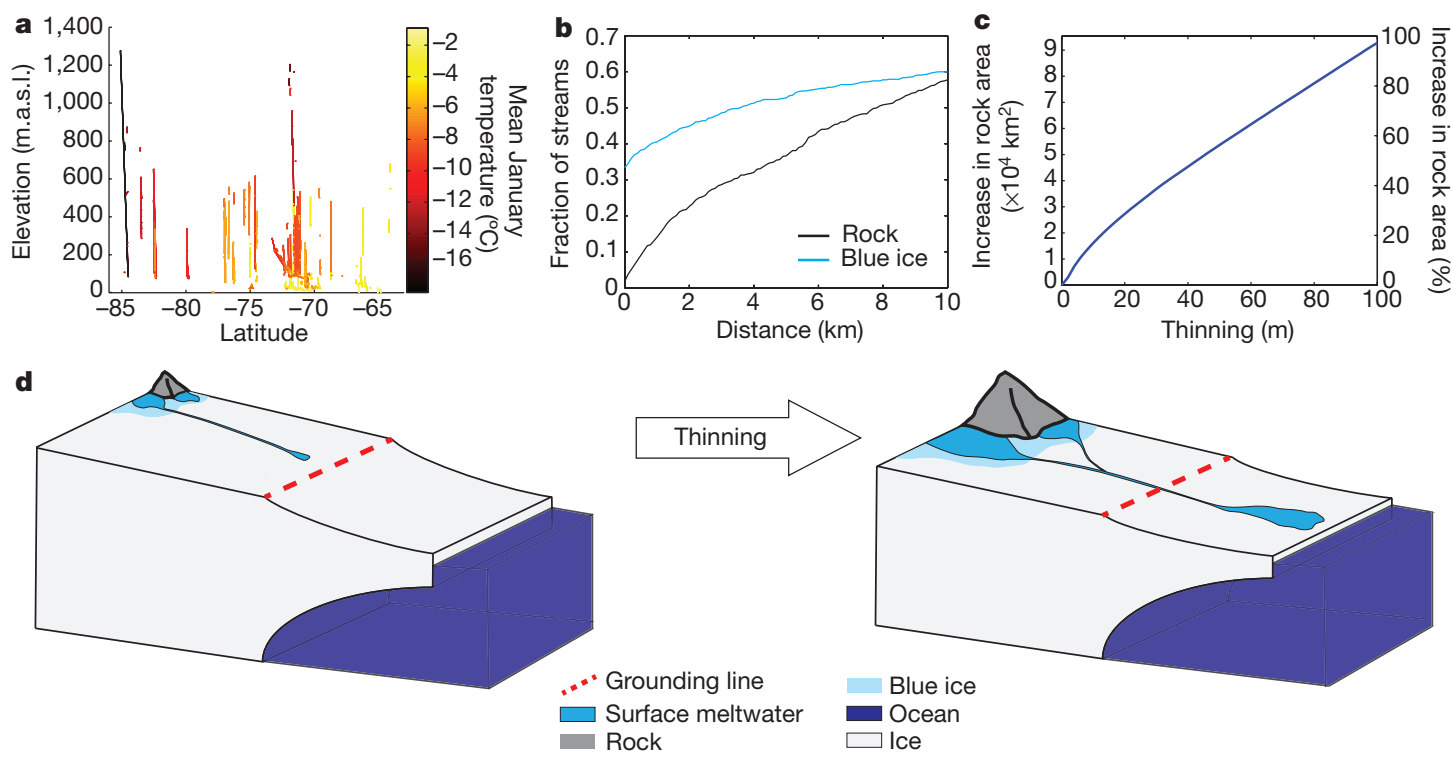

Figure 4 | Controls on the formation of surface drainage networks. a, Elevations and latitudes of drainage systems. Lines connect points corresponding to the upper and lower extremes of each of the 696 surface drainage systems observed (1947-2015). Colours show modelled mean January air temperatures at the upper end of networks (Methods). b, Proximity of upper ends of drainage networks to exposed rock (black) and blue-ice (blue) $(n=696)$. c, Total and percentage increase in continent-wide exposed bedrock as a function of ice-sheet thinning (Methods). d, Enlarged areas of exposed rock and increased melting caused by ice-sheet thinning, leading to enhanced surface drainage. Source Data for this figure are available in the online version of the paper. 
restrict melting to areas with relatively low albedo. Coupling between blue ice, exposed rock and melting is not captured by the commonly used regional climate model RACMO2. This may explain why the model greatly underestimates melt rates over Amery Ice Shelf (Fig. 3c) and predicts very low mean January air temperatures at the locations of high-elevation drainage systems at extreme southerly latitudes (Fig. 4a).

Accumulation of locally derived meltwater has triggered ice-shelf collapse in Antarctica's warmest regions ${ }^{4}$. Large-scale transport of meltwater could accelerate mass loss elsewhere on the continent. For example, a feedback is possible between melting, rock exposure and ice-sheet thinning. As ice thins, more rock will be exposed (Fig. 4c), increasing blue-ice formation and melt, which will enlarge drainage systems (Fig. 4d), increasing delivery of water to ice shelves. If water can access areas vulnerable to hydraulically driven fracture, ice-shelves can collapse, which accelerates upstream thinning ${ }^{4}$.

How different parts of Antarctica's surface drainage system will respond to increased surface melting ${ }^{6}$ will vary. Rock-melt-thinning feedbacks may be most effective where nunataks exist upstream of ice shelves that, owing to their stress state, are vulnerable to collapse. Elsewhere, such as on Nansen Ice Shelf ${ }^{20}$, surface drainage systems deliver meltwater directly into the ocean. How efficiently water is transported depends on changing snow properties and ice-shelf mass balance. Where water flows into snow-covered areas (for example, Fig. 3) snow permeability will control how far water can propagate before soaking into subsurface aquifers ${ }^{17}$. Low ice-shelf slopes (typically 0.001) and complex drainage basin structure (Extended Data Fig. 2) suggest that small changes in ice-shelf thickness could strongly impact drainage efficiency.

Large-scale surface drainage in Antarctica had been considered a rarity. Although the latest ice-sheet model ${ }^{5}$ predict that meltwater accumulation on ice shelves will be critical to future ice-sheet stability, these models do not consider the surface drainage of meltwater. We have shown that widespread and persistent surface drainage moves water great distances from grounded ablation areas, onto and across ice shelves, and into areas that otherwise would not experience meltwater accumulation. Large-scale drainage is likely to be a dominant factor in future ice-sheet stability. Improving the representation of ice-sheet surface hydrology in climate and ice-sheet models will be vital for improving predictions of ice-sheet mass balance and sea-level rise.

Online Content Methods, along with any additional Extended Data display items and Source Data, are available in the online version of the paper; references unique to these sections appear only in the online paper.

Received 2 December 2016; accepted 8 March 2017.

1. Scambos, T. A., Hulbe, C., Fahnestock, M. \& Bohlander, J. The link between climate warming and break-up of ice shelves in the Antarctic Peninsula. J. Glaciol. 46, 516-530 (2000).

2. Rott, H., Skvarca, P. \& Nagler, T. Rapid collapse of northern Larsen ice shelf. Antarct. Sci. 271, 788-792 (1996)

3. Rignot, E. et al. Accelerated ice discharge from the Antarctic Peninsula following the collapse of Larsen B ice shelf. Geophys. Res. Lett. 31, L18401 (2004).

4. De Rydt, J., Gudmundsson, G., Rott, H. \& Bamber, J. Modeling the instantaneous response of glaciers after the collapse of the Larsen B Ice Shelf. Geophys. Res. Lett. 42, 5355-5363 (2015).

5. DeConto, R. M. \& Pollard, D. Contribution of Antarctica to past and future sea-level rise. Nature 531, 591-597 (2016).

6. Trusel, L. D. et al. Divergent trajectories of Antarctic surface melt under two twenty-first-century climate scenarios. Nat. Geosci. 8, 927-932 (2015).
7. Zwally, J. H. et al. Surface melt-induced acceleration of Greenland ice-sheet flow. Science 297, 218-222 (2002)

8. Das, S. B. et al. Fracture propagation to the base of the Greenland ice sheet during supraglacial lake drainage. Science 320, 778-781 (2008).

9. Lüthje, M., Pedersen, L. T., Reeh, N. \& Greuell, W. Modelling the evolution of supraglacial lakes on the West Greenland ice-sheet margin. J. Glaciol. 52, 608-618 (2006).

10. Banwell, A. F. et al. Supraglacial lakes on the Larsen B ice shelf, Antarctica, and at Paakitsoq, West Greenland: a comparative study. Ann. Glaciol. 55, 1-8 (2014)

11. Winther, J. G., Elvehøy, H., Bøggild, C. E., Sand, K. \& Liston, G. Melting, runoff and the formation of frozen lakes in a mixed snow and blue-ice field in Dronning Maud Land, Antarctica. J. Glaciol. 42, 271-278 (1996).

12. Langley, E. S., Leeson, A. A., Stokes, C. R. \& Jamieson, S. S. R. Seasonal evolution of supraglacial lakes on an East Antarctic outlet glacier. Geophys. Res. Lett. 43, 8563-8571 (2016).

13. Phillips, H. A. Surface meltstreams on the Amery Ice Shelf, East Antarctica. Ann Glaciol. 27, 177-181 (1998).

14. Swithinbank, C. W. in Satellite Image Atlas of Glaciers of the World: Antarctica (eds Williams, R. S. \& Ferrigno, J. G.) USGS Prof. Paper 1386-B (USGS, 1988).

15. Kingslake, J., Ng, F. \& Sole, A. Modelling channelized surface drainage of supraglacial lakes. J. Glaciol. 61, 185-199 (2015).

16. Leeson, A. A. et al. Supraglacial lakes on the Greenland ice sheet advance inland under warming climate. Nat. Clim. Chang. 5, 51-55 (2015).

17. Lenaerts, J. T. M. et al. Meltwater produced by wind-albedo interaction stored in an East Antarctic ice shelf. Nat. Clim. Chang. 7, 58-62 (2017).

18. Banwell, A. F., MacAyeal, D. R. \& Sergienko, O. V. Breakup of the Larsen B Ice Shelf triggered by chain reaction drainage of supraglacial lakes. Geophys. Res. Lett. 40, 5872-5876 (2013).

19. Rack, W. \& Rott, H. Pattern of retreat and disintegration of the Larsen B ice shelf, Antarctic Peninsula. Ann. Glaciol. 39, 505-510 (2004).

20. Bell, R. E. et al. Antarctic ice shelf potentially stabilized by export of meltwater in surface river. Nature http://dx.doi.org/10.1038/nature22048 (this issue, 2017).

21. Reynolds, J. M. Lakes on George VI Ice Shelf, Antarctica. Polar Rec. 20, 425-432 (1981)

22. Leppäranta, M., Järvinen, $0 . \&$ Mattila, O.-P. Structure and life cycle of supraglacial lakes in Dronning Maud Land. Antarct. Sci. 25, 457-467 (2013).

23. Liston, G. E., Bruland, O. Elvehøy, H. \& Sand, K. Below-surface ice melt on the coastal Antarctic ice sheet. J. Glaciol. 45, 273-285 (1999).

24. Box, J. E. et al. Greenland ice sheet albedo feedback: thermodynamics and atmospheric drivers. Cryosphere 6, 821-839 (2012).

25. Das, I. et al. Influence of persistent wind scour on the surface mass balance of Antarctica. Nat. Geosci. 6, 367-371 (2013).

26. Hui, F. et al. Mapping blue-ice areas in Antarctica using ETM + and MODIS data. Ann. Glaciol. 55, 129-137 (2014)

27. Bintanja, R. \& Reijmer, C. H. Meteorological conditions over Antarctic blue-ice areas and their influence on the local surface mass balance. J. Glaciol. 47, 37-50 (2001)

28. Depoorter, M. A., Bamber, J. L., Griggs, J. A., Lenaerts, J. T. M. \& Ligtenberg, S. R. M. Calving fluxes and basal melt rates of Antarctic ice shelves. Nature 502, 89-92 (2013).

Acknowledgements We acknowledge funding from NASA grant number NNX14AH79G, NSF grant numbers GG008566 and 1443534, and the Old York Foundation. We also thank I. Cordero for assisting with meltwater feature digitization. We thank J. Lenaerts for sharing RACMO2 climate model output.

Author Contributions J.K. led the project and the preparation of the manuscript J.C.E. mapped surface drainage in selected locations. I.D. led analysis of climate model output. R.E.B., along with the other authors, assisted with preparation of the manuscript.

Author Information Reprints and permissions information is available at www.nature.com/reprints. The authors declare no competing financial interests. Readers are welcome to comment on the online version of the paper. Publisher's note: Springer Nature remains neutral with regard to jurisdictional claims in published maps and institutional affiliations. Correspondence and requests for materials should be addressed to J.K. (j.kingslake@columbia.edu).

Reviewer Information Nature thanks A. F. Banwell, G. Flowers and the other anonymous reviewer(s) for their contribution to the peer review of this work. 


\section{METHODS}

Continent-wide survey of satellite imagery and aerial photography. We used the Landsat Image Mosaic of Antarctica (LIMA) ${ }^{29}$, individual Landsat tiles, Aster imagery and WorldView imagery, to identify features on the surface of the ice sheet and ice shelves created by surface meltwater drainage between 1947 and 2015. LIMA was the primary data source, with the other sources of imagery supplementing LIMA further south than $82.5^{\circ} \mathrm{S}$, where Landsat does not reach, and in a few areas where surface drainage was evident in other imagery but not in LIMA, presumably owing to weather conditions.

LIMA consists of over 1,000 Landsat ETM + scenes acquired primarily between 1999 and 2003 that have been mosaicked over Antarctica into one, nearly cloudfree image. Images are natural colour and pan-sharpened to a spatial resolution of $15 \mathrm{~m}$. The meltwater-drainage features easiest to identify unequivocally in LIMA were surface streams. These features often appeared darker or more blue in colour than the surrounding ice and we mapped them where their meandering or braided plan-form structure indicated that they were formed by water flow. Where LIMA suggested a drainage feature, but the imagery's spatial resolution was insufficient to unequivocally identify the feature, we inspected higherresolution WorldView imagery using an online tool (http://applications.pgc. umn.edu/viewers/antarctica/). In many cases this allowed us to see in great detail meltwater-drainage features suggested by LIMA imagery.

We took a conservative approach, discounting linear features that could have been produced by ice flow or wind and meltwater features that are not produced by the movement of water, such as linear ponds, by identifying features as streams only where a feature clearly undulated or meandered in a manner reminiscent of a typical surface stream. This conservative approach means that many additional features exist in LIMA that could potentially be interpreted as evidence of surface drainage.

The timing of satellite imagery acquisition in the year is important. Melting and drainage-system development is often restricted to the warmest parts of the summer and the dates of acquisition of images in LIMA and in the online WorldView archive vary. Our limited temporal coverage leads us to underestimate the extent of surface meltwater drainage in areas where the corresponding LIMA image and the WorldView imagery available online were acquired at a time of year when there is little melt. Future work could study multiple Landsat and WorldView images from every location to better quantify the spatial coverage of surface drainage.

We mapped each end of each water-carved surface drainage network and extracted corresponding ice-surface elevations from the Bedmap2 compilation ${ }^{30}$. We also extracted the ice-surface flow velocity ${ }^{31}$ at the upper end of each drainage network. In selected areas we searched archived Landsat and Aster imagery, and US Geological Survey (USGS) aerial photography to characterize changes in drainage during single melt seasons (for example, Fig. 3 ) and the persistence of surface drainage over decades (for example, Extended Data Fig. 4). We obtained Landsa and Aster imagery from the website EarthExplorer (http://earthexplorer.usgs.gov/) hosted by the USGS and USGS photography from the Univ. of Minnesota's Polar Geospatial Center (PGC) website (http://www.pgc.umn.edu/). WorldView imagery was inspected in the PGC's online tool (http://applications.pgc.umn.edu/viewers/) and in some cases (over Shackleton Glacier) obtained directly from PGC. Extended Data Fig. 4 demonstrates that surface drainage has persisted in several locations for decades, but this figure is far from a comprehensive record of all instances of surface drainage in these locations. Large data gaps, cloud cover and ambiguity as to whether a particular feature is evidence of meltwater drainage mean that many instances of surface meltwater drainage probably remain undetected.

Extended Data Table 1 lists the satellite and aerial imagery used in each figure and provides an identifier for each image. Extended Data Table 2 lists the imagery containing evidence of surface meltwater drainage over the last several decades, plotted in Extended Data Fig. 4.

Digitizing surface drainage features. To digitize surface features on Shackleton Glacier (Fig. 2e) and Amery Ice Shelf (Fig. 3 and Extended Data Fig. 2a), we used the geographic information systems package ArcMap (http://desktop.arcgis. com). Melt-pond area evolution on Amery Ice Shelf was computed by mapping the boundary of the pond from multiple natural-colour pan-sharpened Landsat images. Uncertainties in melt-pond areas were computed as the product of the perimeter of each pond and the resolution of the pan-sharpened imagery $(15 \mathrm{~m})$. The rate of migration of the pond's down-ice-shelf margins was computed from the displacement of this margin between images and the time separation of image acquisition. The uncertainty in the migration speed was computed by combining the uncertainty in margin location $(15 \mathrm{~m})$ from each grid direction in quadrature (the uncertainty in the time of acquisition is negligible compared to the spatial uncertainty).
Analysis of regional climate model output. The regional climate model RACMO2 simulates atmospheric circulation across Antarctica on a $27-\mathrm{km}$ grid and is forced at the model-domain boundaries by reanalysis data ${ }^{32}$. Model output is available for every day between 1 January 1979 and 31 December 2015. We computed the January-mean air temperature at a height of $2 \mathrm{~m}$ above the ground in each grid cell over the period 1979-2015 and displayed its $0^{\circ} \mathrm{C}$ contour in Fig. 1. To compute time series of 2-m air temperature at the location of the melt pond on Amery Ice Shelf (Fig. 3) we extracted values corresponding to the closest grid cell in the model output. We also extracted the long-term January-mean 2-m air temperature at the upper end of each stream (Fig. 4a).

We find that RACMO2 predicts very cold January 2-m air temperatures in locations where we see persistent drainage systems (Fig. 4a) and hypothesize that this is due to low albedo surfaces that are not included in the model. Using an alternative RACMO2 output that contains information about surface temperatures important for surface melting (called the 'skin temperature') does not affect this conclusion. The simulated skin temperature is consistently lower than the simulated $2-\mathrm{m}$ temperature used above, with this difference being largest in mountain ranges. For example, over the Trans-Antarctic Mountains the difference in the mean January values of the $2-\mathrm{m}$ air temperature and the skin temperature ranges between $0.2^{\circ} \mathrm{C}$ and $6.9^{\circ} \mathrm{C}$.

Comparing order-of-magnitude modelled and observed meltwater on Amery Ice Shelf. For each day of the 2014/15 melt season we integrated the mass of meltwater predicted by RACMO2 over the entire Amery Ice Shelf. In Fig. $3 \mathrm{~b}$ we plot the cumulative meltwater volume using a water density of $1,000 \mathrm{~kg} \mathrm{~m}^{-3}$. For the sake of comparison of order-of-magnitude meltwater volumes, we assume that the melt pond depicted in Fig. $3 \mathrm{~b}$ had a uniform depth of $1 \mathrm{~m}$ (close to the mean depth computed for Larsen B Ice Shelf ${ }^{10}, 0.8 \mathrm{~m}$ ), to compute the 'observed' volumes plotted in Fig. 3b. Upper and lower estimates of lake volume are obtained by assuming a lake depth of $1 \mathrm{~cm}$ as a lower bound and $10 \mathrm{~m}$ as an upper bound, as well as taking the lower and upper bound on mapped lake areas (taking into account the uncertainty estimated in the mapped lake areas). The vertical lines in Fig. $3 \mathrm{c}$ represent the range between these upper and lower bounds.

The melt pond's peak volume is estimated as $4.5 \times 10^{7} \mathrm{~m}^{3}$ (assuming a depth of $1 \mathrm{~m}$ ), around four orders of magnitude larger than the RACMO2-modelled melt production for the entire Amery Ice Shelf during the same period. Amery Ice Shelf is adjacent to nunataks and is partly covered by blue ice (Extended Data Fig. 2). RACMO2 does not account for spatial variations in albedo and so we hypothesize that the model may not simulate sufficient heat absorption to generate realistic melt rates.

A more precise comparison between modelled and observed melt volumes would use multi-spectral imagery ${ }^{33,34}$ to map the depth of the pond and compute volumes rather than estimate them using an assumed mean depth, as we have done here. A more precise comparison would be worthwhile if it would allow us to compute a water budget for the pond and compute how much water accesses an unobserved englacial drainage system-either a firn aquifer or an englacial system of fractures or conduits. This may be possible in future work using regional climate models that include spatially variable albedo and can realistically simulate melt rates.

Computing proximity to blue ice and exposed rock. Masks of blue ice and exposed rock ${ }^{26}$ were produced through calibrated characterization of surface spectral properties determined from Landsat imagery. We used ArcMap to compute the planar distance from the upper end of each mapped drainage system to the nearest rock and to the nearest blue ice. Figure $4 \mathrm{~b}$ and Extended Data Fig. 8 display the results as a proportion of all the streams that originate within a range of distances of rock and blue ice $(n=696)$.

Estimating increase in exposed-rock area due to ice-sheet thinning. Using the Bedmap2 continent-wide ice thickness data set $^{30}$, we estimated the area of the ice sheet that is thinner than a range of values from 0 to $100 \mathrm{~m}$, to estimate how much bedrock would be exposed in response to ice-sheet thinning. Figure $4 \mathrm{c}$ plots the total increase in bedrock area and expresses this as a percentage of the current total area of exposed rock. The current total area of exposed rock was determined from the rock mask supplied with Bedmap2. Bedmap2 has a spatial resolution of $1 \mathrm{~km}$. Alternatively, the current area of exposed rock could be computed from the higher resolution $(15 \mathrm{~m})$ mask produced from Landsat imagery ${ }^{26}$. If we had ice-thickness data of similarly high spatial resolution, the Landsat-derived mask would yield a more accurate estimate of the impact of thinning on rock exposure. However, as Bedmap2 is the highest-resolution continent-wide ice thickness product available, we instead use the lower-resolution rock mask supplied with this product.

Data availability. The Landsat Image Mosaic of Antarctica (LIMA) can be viewed and downloaded at https://lima.usgs.gov/. Landsat and Aster tiles can be obtained from http://earthexplorer.usgs.gov/. WorldView imagery can either be inspected 


\section{RESEARCH LETTER}

using the Polar Geospatial Center's (PGC) online tool (http://applications.pgc. umn.edu/viewers/) or obtained by contacting PGC directly. Trimetrogon aerial photography dating from 1947 can be downloaded from http://www.pgc.umn. edu/. Aerial reconnaissance photography is hosted at http://depts.washington.edu/ cosmolab/ant_web/shackleton/content/. RACMO2 climate model output can be obtained by contacting the authors of ref. 17 or ref. 32 directly.

29. Bindschadler, R. et al. The Landsat image mosaic of Antarctica. Remote Sens. Environ. 112, 4214-4226 (2008).

30. Fretwell, P. et al. Bedmap2: improved ice bed, surface and thickness datasets for Antarctica. Cryosphere 7, 375-393 (2013).
31. Rignot, E., Mouginot, J. \& Scheuchl, B. Ice flow of the Antarctic ice sheet. Science 333, 1427-1430 (2011).

32. Van Wessem, J. M. et al. Improved representation of East Antarctic surface mass balance in a regional atmospheric climate model. J. Glaciol. 60, 761-770 (2014)

33. Pope, A. et al. Estimating supraglacial lake depth in West Greenland using Landsat 8 and comparison with other multispectral methods. Cryosphere 10, 15-27 (2016).

34. Sneed, W. A. \& Hamilton, G. Evolution of melt pond volume on the surface of the Greenland Ice Sheet. Geophys. Res. Lett. 34, L03501 (2007).

35. Haran, T., Bohlander, J., Scambos, T., Painter, T \& Fahnestock, M. MODIS Mosaic of Antarctica 2003-2004 (MOA2004) Image Map http://dx.doi.org/10.7265/ N5ZK5DM5 (National Snow and Ice Data Center, 2005). 
a

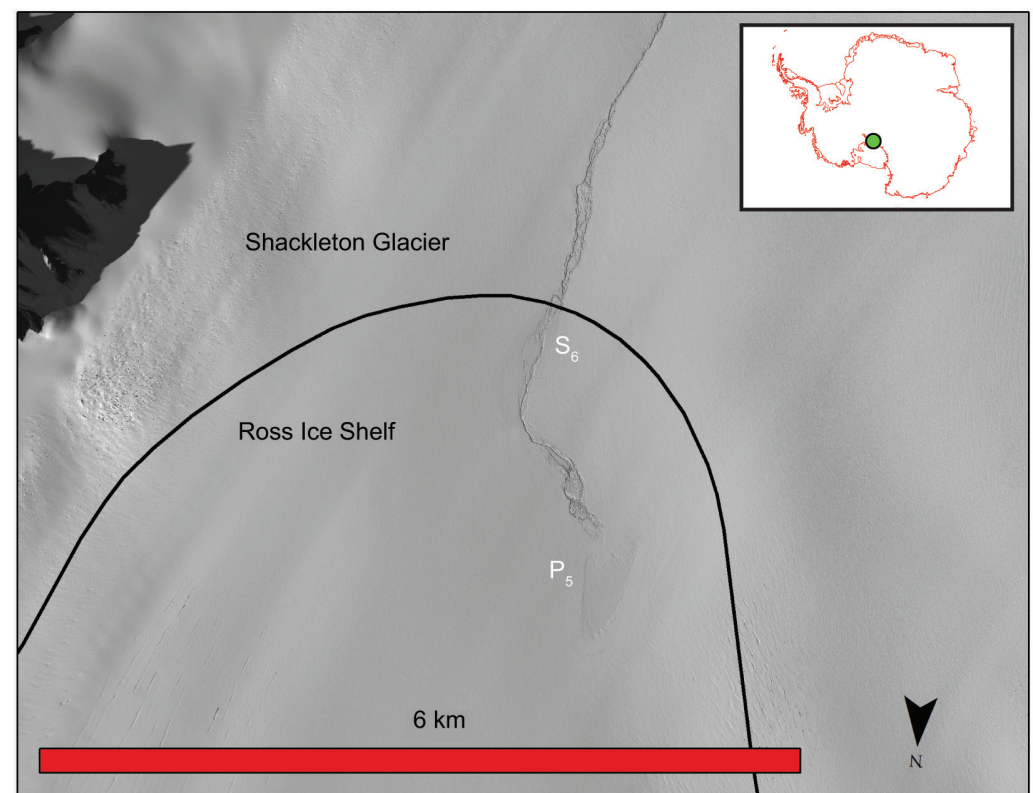

b

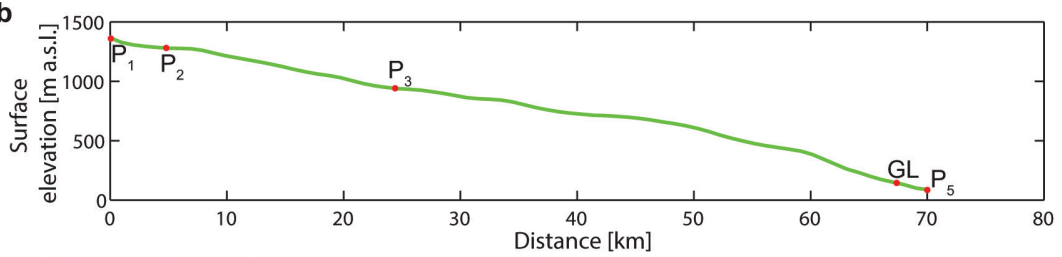

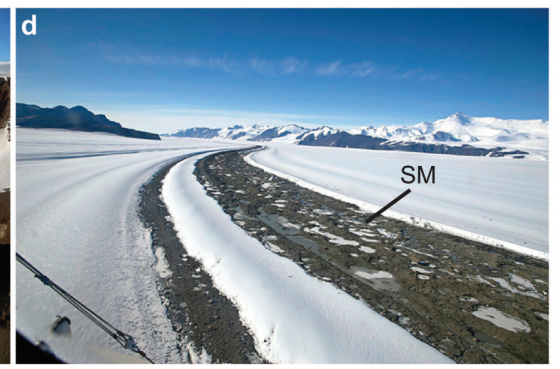

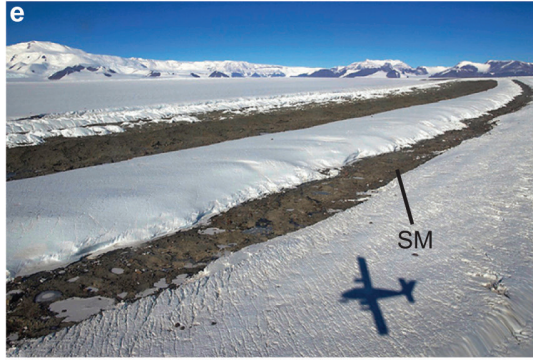

Extended Data Figure 1 | Drainage on Shackleton Glacier. a, WorldView 1 image showing a surface stream flowing from Shackleton Glacier, across the grounding line ${ }^{28}$ (black), onto the Ross Ice Shelf, from 11 February 2010. See also Fig. 2j. b, Shackleton Glacier surface profile extracted from Bedmap2 (ref. 30). c-f, Aerial reconnaissance photography over

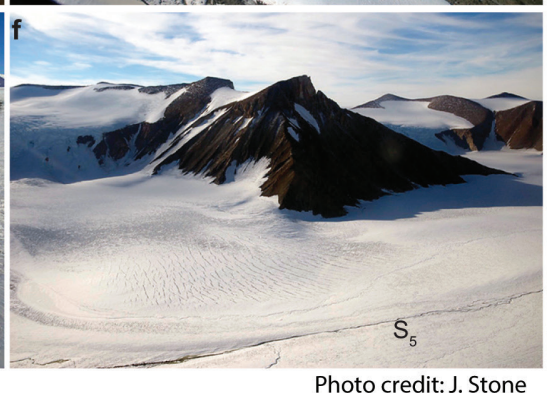

Shackleton Glacier from 12 January 2010. Photo credit J. Stone, University of Washington, 2010. c, A large pond, $\mathrm{P}_{1}$, at the head of Swithinbank Moraine, SM. d, Meltwater ponds on SM. e, Further surface ponding on SM. f, A meltwater channel, $S_{5}$ running parallel to ice flow. Source data for this figure is available in the HTML version of the paper. 

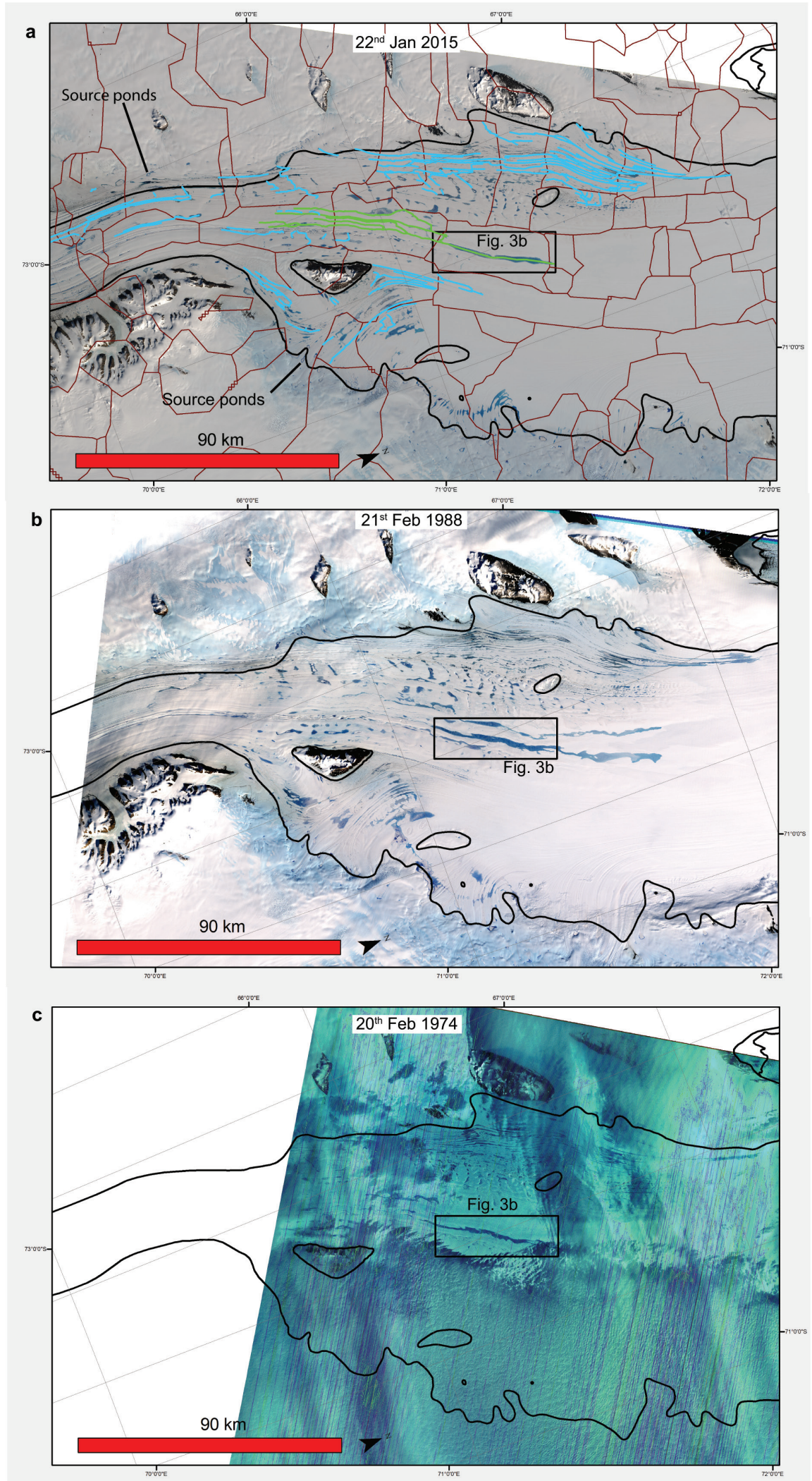

Extended Data Figure 2 Drainage onto and across Amery Ice Shelf. Landsat imagery from 2015 (a), 1988 (b) and 1974 (c). The black boxes show the extent of Fig. 3b. Drainage basins computed from Bedmap2 (ref. 30) are shown in red in a. The drainage network that feeds the large pond in Fig. 3b is shown in green and other major drainage systems are shown in blue. See inset in Fig. 3 b for location in East Antarctica. The grounding line $\mathrm{e}^{28}$ is in black. 

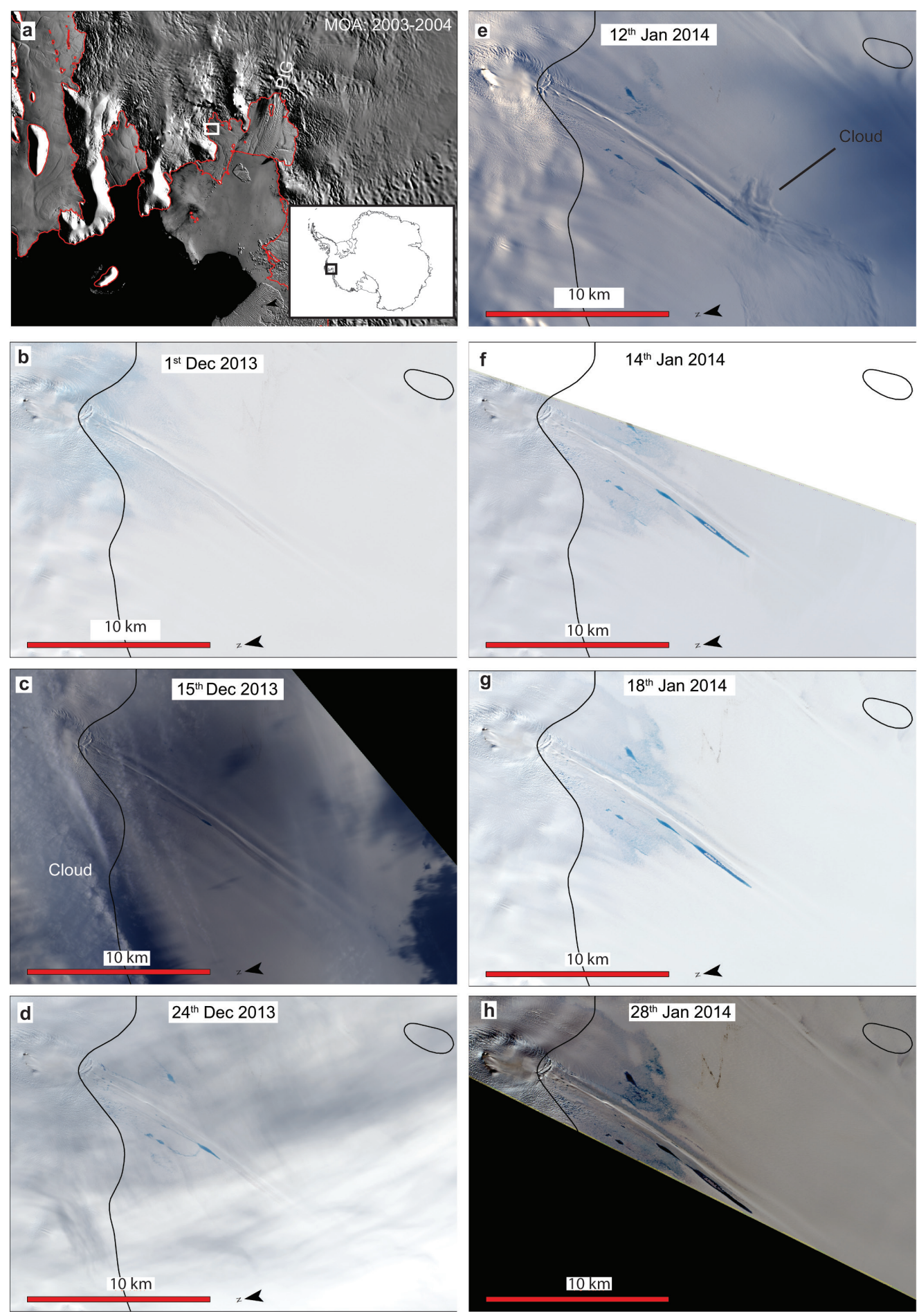

Extended Data Figure 3 | Drainage across Pine Island Ice Shelf. a, MODIS Mosaic of Antarctica (MOA) ${ }^{35}$ image showing the ice shelf and surroundings, including Pine Island Glacier (PIG). Inset shows location in West Antarctica. White box shows the extent of the images in the other panels. b-h, Satellite imagery showing the growth of a melt pond during the 2013/14 melt season. The grounding line ${ }^{28}$ is in black. 


\section{RESEARCH LETTER}

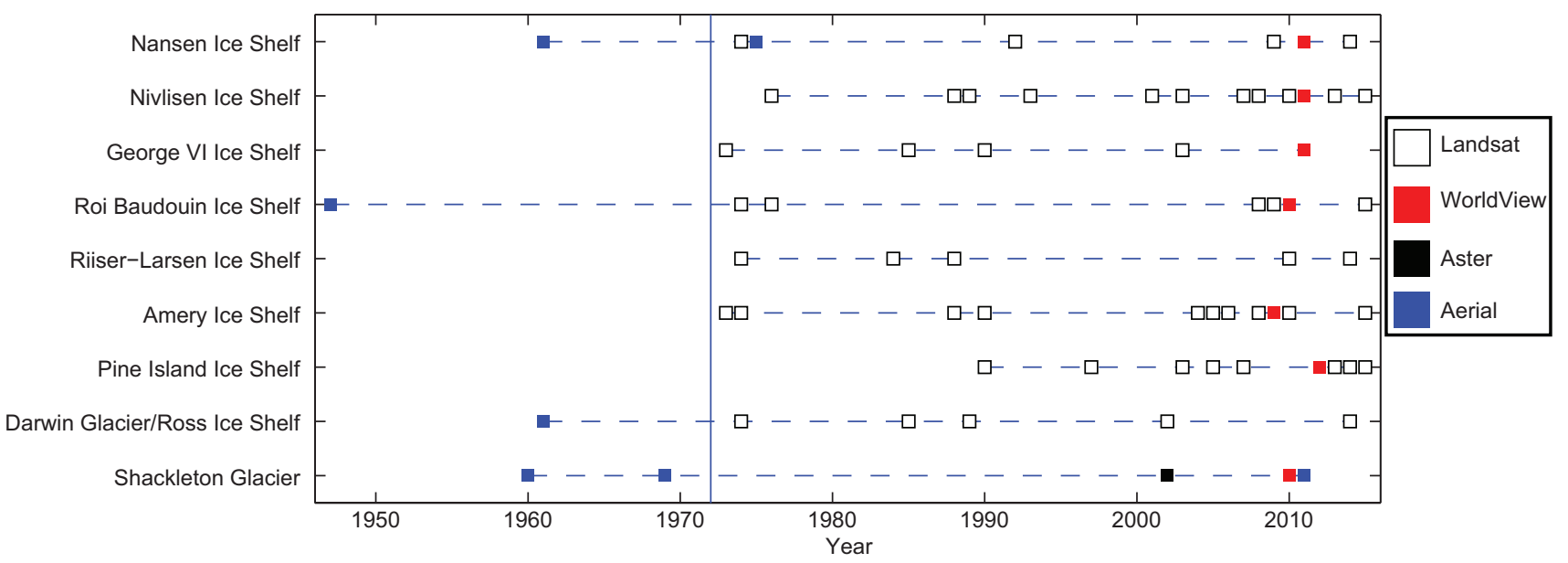

Extended Data Figure 4 | Persistence of nine surface drainage systems. Squares show the year of observations of surface drainage in each system. This figure represents a lower bound on the occurrence of drainage in imagery, WorldView imagery, Aster imagery or aerial photography. The vertical line at 1972 marks the launch of the first Landsat satellite. See Extended Data Table 2 for details. 
Roi Baudouin Ice Shelf, 21 $1^{\text {st }}$ Feb 1947

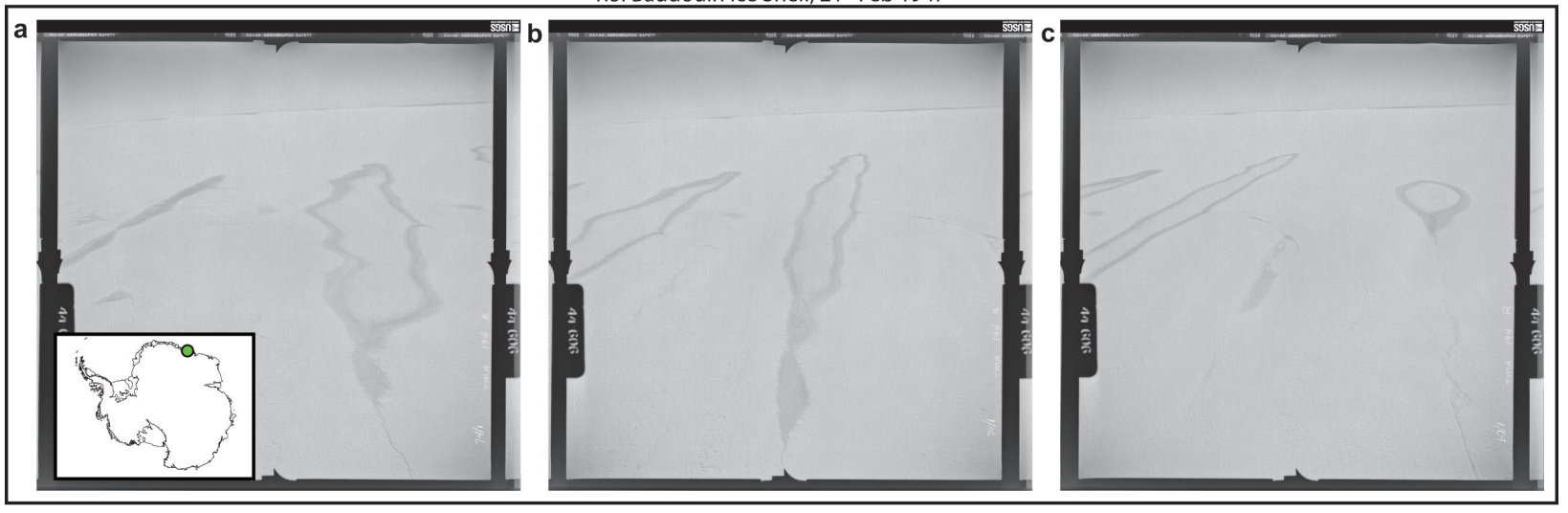

d

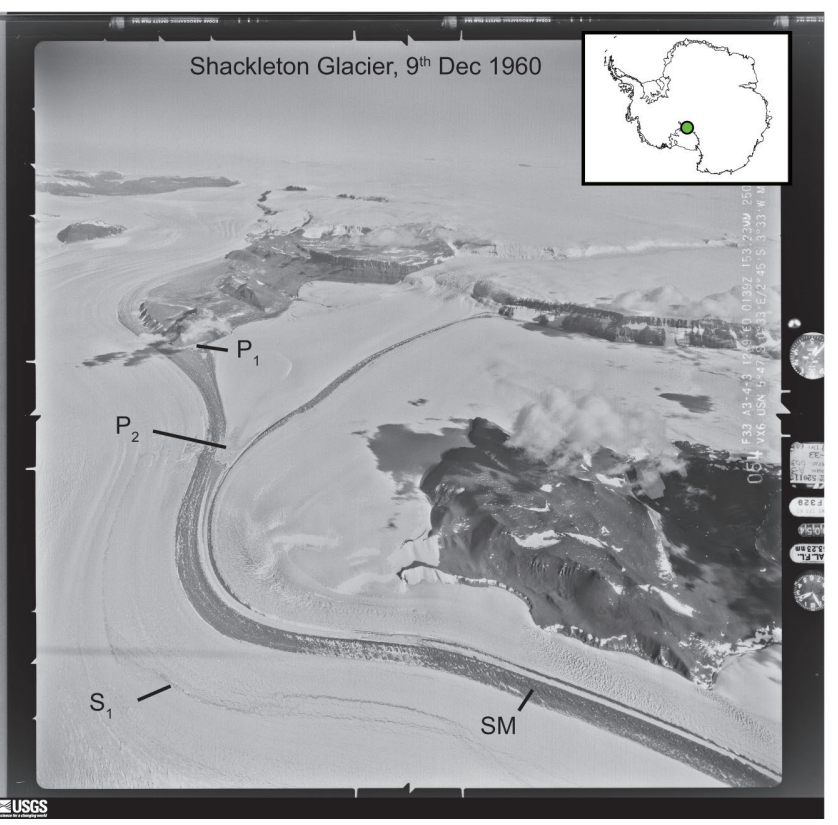

Extended Data Figure 5 | Pre-satellite era aerial photography of persistent surface drainage systems. a-c, Oblique aerial photography of melt ponds on Roi Baudouin Ice Shelf, fed by surface streams. Inset shows location in West Antarctica. Look direction is approximately northwards from the grounding line. The pond that appears on the right in a can also be seen in $\mathbf{b}$ and $\mathbf{c}$. d, Aerial photograph of Shackleton Glacier, 9 December 1960 , showing meltwater features $\mathrm{P}_{1}, \mathrm{P}_{2}$ and $\mathrm{S}_{1}$, that are visible in more recent satellite imagery and aerial photographs (Fig. 2). 


\section{RESEARCH LETTER}
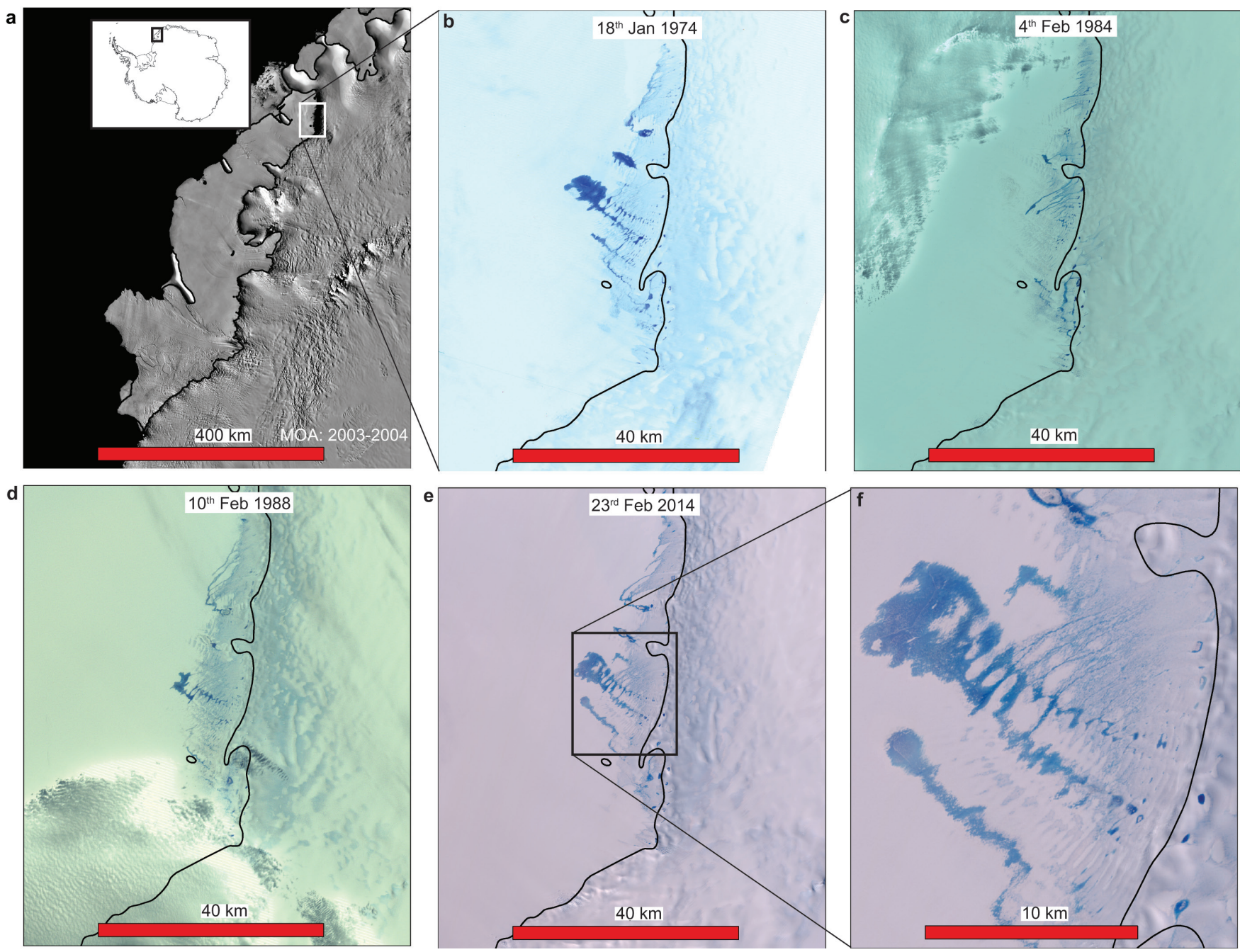

Extended Data Figure 6 | Surface drainage across the Riiser-Larsen Ice Shelf. a, White box shows the location of the images shown in the other panels. Background image is from MOA. The inset shows the location in East Antarctica. b-e, Landsat images from 1974, 1984, 1988 and 2014. f, Enlarged view of melt ponds in e. In all panels the grounding line $e^{28}$ is in black. 

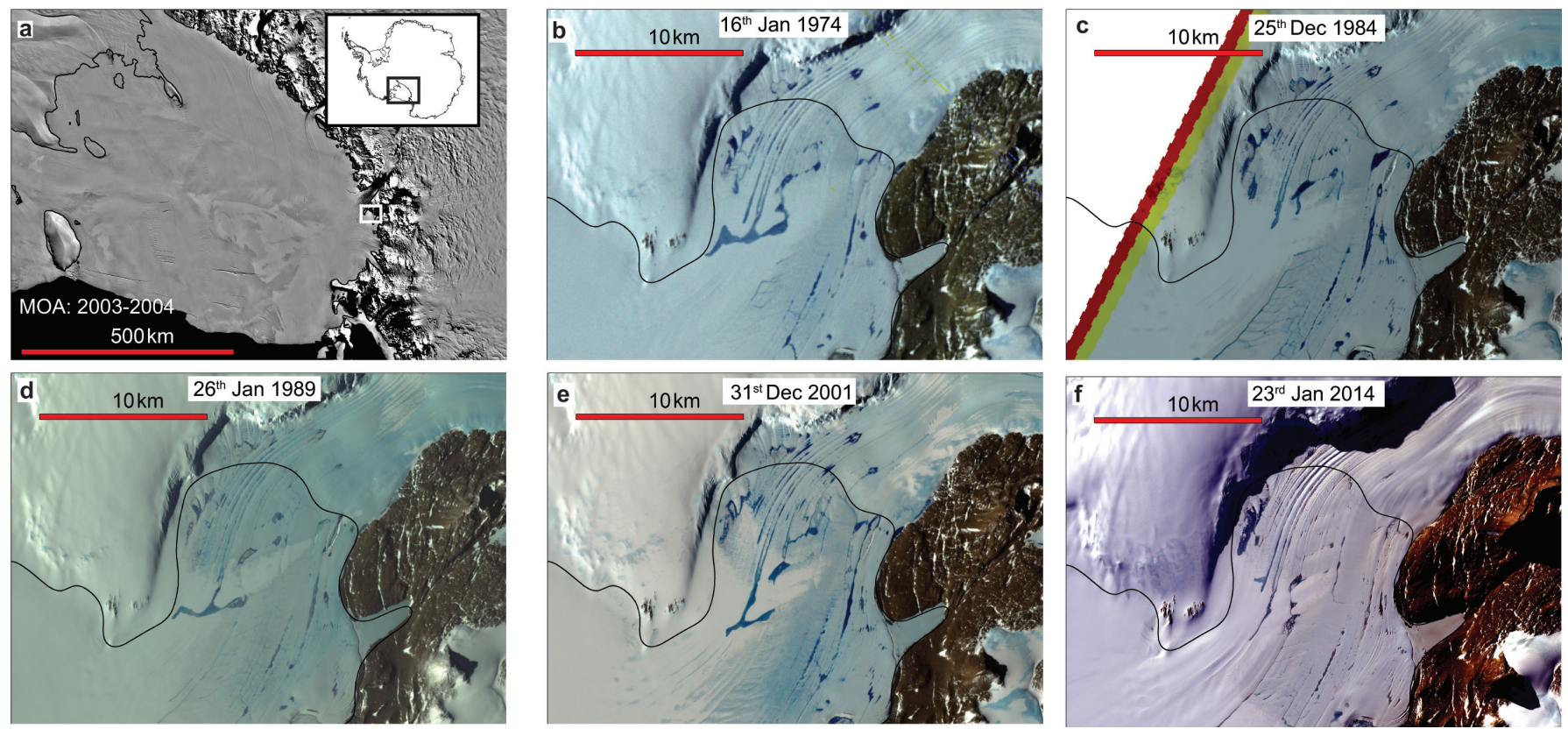

Extended Data Figure 7 | Drainage on Ross Ice Shelf, downstream of Darwin Glacier. a, The location of the other panels is shown in white, background image is from MOA. Inset shows location in Antarctica. $\mathbf{b}-\mathbf{f}$, Landsat satellite images showing meltwater ponding and drainage crossing the grounding line ${ }^{28}$ shown in black, over a 40 -year period. 


\section{RESEARCH LETTER}

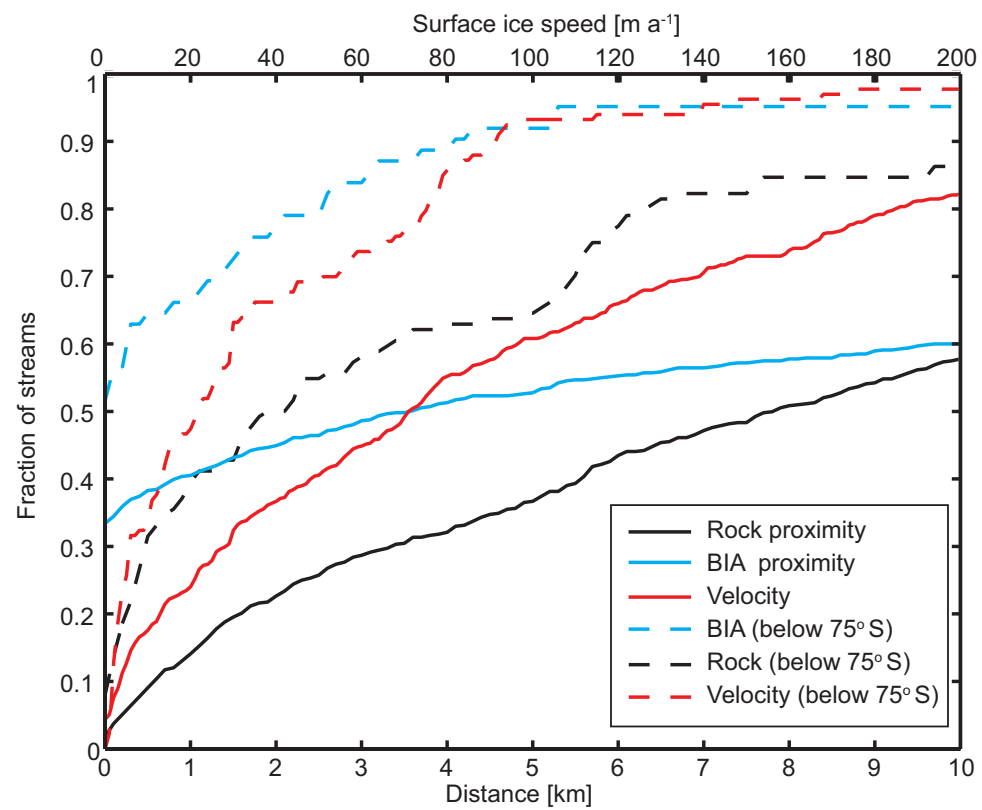

Extended Data Figure 8 Ice-flow speed and proximity to rock and blue ice at surface streams. Proximity of upper ends of streams to exposed rock (black) and blue-ice areas (blue) and ice-flow speed at the surface at the upper end of the streams, across the entire continent (solid curves) and further south than $75^{\circ} \mathrm{S}$ (dashed curves) $(n=696)$. Source data for this figure is available in the HTML version of the paper. 
Extended Data Table 1 | Information on the imagery used for the figures

\begin{tabular}{|c|c|c|c|}
\hline Panel & Location & Platform & Identifier \\
\hline Fig. 1a & Larsen B Ice Shelf & Landsat 3 & LM32311061979032AAA08 \\
\hline Fig. 1b & Riiser-Larsen Ice Shelf & Landsat 5 & LT51781111984358XXX03 \\
\hline Fig. 1c & Nivlisen Ice Shelf & Landsat 8 & LC81671102015014LGN00 \\
\hline Fig. 1d & Roi Baudouin Ice Shelf & Landsat 8 & LC81541102015003LGN00 \\
\hline Fig. 1e & Amery Ice Shelf & Landsat 4 & LT41271101988052XXX10,LT41271111988052XXX03 \\
\hline Fig. $1 f$ & Shackleton Ice Shelf & Aerial photography & CA013932V0070 \\
\hline Fig. $1 \mathrm{~g}$ & Nansen Ice Shelf & Landsat 8 & LC82211312014005LGN00 \\
\hline Fig. 1h & Rennick Glacier & Landsat 8 & LC80681102014037LGN00 \\
\hline Fig. 1i & Darwin Glacier/Ross Ice Shelf & Landsat 8 & LC80021262014023LGN00 \\
\hline Fig. $1 \mathrm{j}$ & $\begin{array}{l}\text { Ford Ranges/Sulzberger Ice } \\
\text { Shelf }\end{array}$ & Landsat 8 & LC80281152015016LGN00 \\
\hline Fig. $1 \mathrm{k}$ & Pine Island Ice Shelf & Landsat 8 & LC82321132014018LGN00 \\
\hline Fig. 1l & George VI Ice Shelf & Landsat 7 & LE72181102003010PFS00 \\
\hline Fig. $2 a$ & Shackleton Glacier & Aerial photography & CA218933R0026 \\
\hline Fig. $2 b$ & Shackleton Glacier & Aerial photography & CA218933R0017 \\
\hline Fig. 2c & Shackleton Glacier & $\begin{array}{l}\text { Reconnaissance } \\
\text { photography }\end{array}$ & N/A \\
\hline Fig. 2d & Shackleton Glacier & Aster & AST_L1T_00301042002162335_20150421034209_32733 \\
\hline Fig. $2 f$ & Shackleton Glacier & WorldView 1 & WV01_20100211195819_102001000AD8C300_10FEB11195819 \\
\hline Fig. $2 g$ & Shackleton Glacier & WorldView 1 & WV01_20100211195819_102001000AD8C300_10FEB11195819 \\
\hline Fig. $2 \mathrm{~h}$ & Shackleton Glacier & WorldView 1 & WV01_20100211195817_102001000AD8C300_10FEB11195817 \\
\hline Fig. $2 i$ & Shackleton Glacier & WorldView 1 & WV01_20100211195816_102001000AD8C300_10FEB11195816 \\
\hline Fig. $2 \mathrm{j}$ & Shackleton Glacier & WorldView 1 & WV01_20100211195815_102001000AD8C300_10FEB11195815 \\
\hline Fig. $2 k$ & Shackleton Glacier & WorldView 1 & WV01_20100211195815_102001000AD8C300_10FEB11195815 \\
\hline Fig. 3a & Amery Ice Shelf & Landsat 8 & $\begin{array}{l}\text { LC81271102015022LGNO0, LC81271122015022LGN00, } \\
\text { LC81271112015022LGN00 }\end{array}$ \\
\hline Fig. 3b & Amery Ice Shelf & Landsat 8 & LC81261112015015LGN00 \\
\hline Ext. Fig. 1a & Shackleton Glacier & WorldView 1 & WV01_20100211195815_102001000AD8C300_10FEB11195815 \\
\hline Ext. Fig. 1c-1f & Shackleton Glacier & $\begin{array}{l}\text { Reconnaissance } \\
\text { photography }\end{array}$ & \\
\hline Ext. Fig. 2a & Amery Ice Shelf & Landsat 8 & $\begin{array}{l}\text { LC81271102015022LGNOO, LC81271122015022LGNO0, } \\
\text { LC81271112015022LGNOO }\end{array}$ \\
\hline Ext. Fig. $2 b$ & Amery Ice Shelf & Landsat 4 & LT41271101988052XXX10 and LT41271111988052XXX03 \\
\hline Ext. Fig. 2c & Amery Ice Shelf & Landsat 1 & LM11341111974051AAA02 \\
\hline Ext. Fig. 3b & Pine Island Ice Shelf & Landsat 8 & LC82321132013335LGN00 \\
\hline Ext. Fig. 3c & Pine Island Ice Shelf & Landsat 8 & LC81541322013349LGN00 \\
\hline Ext. Fig. 3d & Pine Island Ice Shelf & Landsat 8 & LC82331132013358LGN00 \\
\hline Ext. Fig. $3 e$ & Pine Island Ice Shelf & Landsat 8 & LC81581312014012LGN00 \\
\hline Ext. Fig. $3 f$ & Pine Island Ice Shelf & Landsat 8 & LC81561312014014LGN00 \\
\hline Ext. Fig. $3 g$ & Pine Island Ice Shelf & Landsat 8 & LC82321132014018LGN00 \\
\hline Ext. Fig. 3h & Pine Island Ice Shelf & Landsat 8 & LC82311132014027LGN00 \\
\hline Ext. Fig. $5 a$ & Roi Baudouin Ice Shelf & Aerial Photography & CA019400R0074 \\
\hline Ext. Fig. 5b & Roi Baudouin Ice Shelf & Aerial Photography & CA019400R0070 \\
\hline Ext. Fig. $5 c$ & Roi Baudouin Ice Shelf & Aerial Photography & CA019400R0067 \\
\hline Ext. Fig. 5d & Shackleton Glacier & Aerial photography & CA078633R0054 \\
\hline Ext. Fig. 6b & Riiser-Larsen Ice Shelf & Landsat 1 & LM11911111974018AAA05 \\
\hline Ext. Fig. 6c & Riiser-Larsen Ice Shelf & Landsat 5 & LT51781111984358XXX03 \\
\hline Ext. Fig. 6d & Riiser-Larsen Ice Shelf & Landsat 4 & LM41781111988041AAA03 \\
\hline Ext. Fig. $6 e$ & Riiser-Larsen Ice Shelf & Landsat 8 & LC81801112014054LGN00 \\
\hline Ext. Fig. 6e & Riiser-Larsen Ice Shelf & Landsat 8 & LC81801112014054LGN00 \\
\hline Ext. Fig. 7b & Darwin Glacier/Ross Ice Shelf & Landsat 1 & LM10461191974016AAA04 \\
\hline Ext. Fig. 7c & Darwin Glacier/Ross Ice Shelf & Landsat 5 & LT50551171984360XXX04 \\
\hline Ext. Fig. 7d & Darwin Glacier/Ross Ice Shelf & Landsat 4 & LT40501181989026XXX03 \\
\hline Ext. Fig. $7 \mathrm{e}$ & Darwin Glacier/Ross Ice Shelf & Landsat 7 & LE70481182001365EDC02 \\
\hline Ext. Fig. $7 f$ & Darwin Glacier/Ross Ice Shelf & Landsat 8 & LC80021262014023LGN00 \\
\hline
\end{tabular}

The platform is either the name of the satellite that acquired the imagery (for example, Landsat, WorldView or Aster), aerial photography, which refers to the Trimetrogon aerial photography campaigns undertaken by the US Navy starting in 1947, or reconnaissance photography, which refers to photography taken on a hand-held camera by J. Stone, University of Washington, during a reconnaissance flight over Shackleton Glacier in 2010. 
RESEARCH LETTER

Extended Data Table 2 | Additional information on the evidence for surface meltwater drainage over the last nearly 70 years

\begin{tabular}{|c|c|c|c|}
\hline Location & Year & Platform & Identifier of figure number \\
\hline \multirow[t]{5}{*}{ Shackleton Glacier } & 1960 & Aerial photography & Ext. Fig. 5d \\
\hline & 1969 & Aerial photography & Figs. $2 a$ and $2 b$ \\
\hline & 2002 & Aster & Fig. $2 d$ \\
\hline & 2010 & Reconnaissance photography & Figs. 2c and Ext. Fig. 1 \\
\hline & 2011 & WorldView 1 & Figs. 2f-2k and Ext. Fig. 1 \\
\hline \multirow[t]{7}{*}{ Darwin Glacier/Ross Ice Shelf } & 1961 & Aerial photography & CA074732V0195 \\
\hline & 1974 & Aerial photography & CA244633R0206 \\
\hline & 1974 & Landsat 1 & Ext. Fig. 7b \\
\hline & 1985 & Landsat 5 & Ext. Fig. 7c \\
\hline & 1989 & Landsat 4 & Ext. Fig. 7d \\
\hline & 2002 & Landsat 7 & Ext. Fig. $7 e$ \\
\hline & 2014 & Landsat 8 & Fig. $1 \mathrm{i}$ and Ext. Fig. $7 \mathrm{f}$ \\
\hline \multirow[t]{9}{*}{ Pine Island Ice Shelf } & 1990 & Landsat 4 & LT42321131990024XXX01 \\
\hline & 1997 & Landsat 5 & LT50021131997024XXX01 \\
\hline & 2003 & Landsat 7 & LE72321132003028EDC00 \\
\hline & 2005 & Landsat 7 & LE72331132005024ASN00 \\
\hline & 2007 & Landsat 7 & LE70011132007005ASN00 \\
\hline & 2012 & Landsat 7 & LE72331132012012EDC00 \\
\hline & 2013 & Landsat 7 & LE72311132013016EDC00 \\
\hline & 2014 & Landsat 8 & Fig. 1k and Ext. Fig. 3 \\
\hline & 2015 & Landsat 8 & LC80021132015026LGN00 \\
\hline \multirow[t]{11}{*}{ Amery lce Shelf } & 1973 & Landsat 1 & LM11311111973035AAA05 \\
\hline & 1974 & Landsat 1 & Ext. Fig. 2c \\
\hline & 1988 & Landsat 4 & Ext. Fig. $2 b$ \\
\hline & 1990 & Landsat 4 & LT41281111989349XXX02 \\
\hline & 2004 & Landsat 7 & LE71291102004030ASN01 \\
\hline & 2005 & Landsat 7 & LE71291102005016PFS00 \\
\hline & 2006 & Landsat 7 & LE71261112006014EDC00 \\
\hline & 2008 & Landsat 7 & LE71291112008009PFS00 \\
\hline & 2009 & WorldView 1 & $10100100091 \mathrm{CBA00}$ \\
\hline & 2010 & Landsat 7 & LE71271112010032SGS00 \\
\hline & 2015 & Landsat 8 & Fig. 3a and Ext. Fig. 2a \\
\hline \multirow[t]{5}{*}{ Riiser-Larsen Ice Shelf } & 1974 & Landsat 1 & Ext. Fig. $6 b$ \\
\hline & 1984 & Landsat 5 & Ext. Fig. 6c \\
\hline & 1988 & Landsat 4 & Ext. Fig. 6d \\
\hline & 2010 & Landsat 7 & LE71801112010019ASN00 \\
\hline & 2014 & Landsat 8 & Ext. Figs. $6 e$ and $6 f$ \\
\hline \multirow[t]{7}{*}{ Roi Baudouin Ice Shelf } & 1947 & Aerial photography & Ext. Fig. 5 \\
\hline & 1974 & Landsat 1 & LM11661101974028FAK03 \\
\hline & 1976 & Landsat 2 & LM21651101976045AAA04 \\
\hline & 2008 & Landsat 7 & LE71551102008031SGS00 \\
\hline & 2009 & Landsat 7 & LE71551102009017ASN00 \\
\hline & 2010 & WorldView (GeoEye1) & 463195 \\
\hline & 2015 & Landsat 8 & Fig. 1d \\
\hline \multirow[t]{5}{*}{ George VI Ice Shelf } & 1973 & Landsat 1 & LM12321101973009FAK02 \\
\hline & 1985 & Landsat 5 & LM52171101985057AAA03 \\
\hline & 1990 & Landsat 4 & LT42171101990015XXX04 \\
\hline & 2003 & Landsat 7 & LE72181102003026EDC00 \\
\hline & 2011 & WorldView 1 & 10200100114BF600 \\
\hline \multirow[t]{12}{*}{ Nivlisen Ice Shelf } & 1976 & Landsat 2 & LM21771101976039AAA05 \\
\hline & 1988 & Landsat 4 & LT41671101988012XXX03 \\
\hline & 1989 & Landsat 4 & LT41671101989014XXX04 \\
\hline & 1993 & Landsat 4 & LT41661101993018XXX02 \\
\hline & 2001 & Landsat 7 & LE71651102001001SGS00 \\
\hline & 2003 & Landsat 7 & LE71661102003014SGS00 \\
\hline & 2007 & Landsat 7 & LE71651102007034ASN00 \\
\hline & 2008 & Landsat 7 & LE71651102008005ASN00 \\
\hline & 2010 & Landsat 7 & LE71651102010026ASN00 \\
\hline & 2011 & WorldView 1 & $1020010011 \mathrm{CE} 1300$ \\
\hline & 2013 & Landsat 7 & LE71641102013027ASN00 \\
\hline & 2015 & Landsat 8 & Fig. 1c \\
\hline \multirow[t]{7}{*}{ Nansen Ice Shelf } & 1961 & Aerial photography & CA073631L0122 \\
\hline & 1974 & Landsat 1 & LM10641141974016AAA02 \\
\hline & 1975 & Aerial photography & CA238432V0020 \\
\hline & 1992 & Landsat 4 & LT40631131992030XXX02 \\
\hline & 2009 & Landsat 7 & LE70621132009021EDC00 \\
\hline & 2011 & WorldView & 102001000FC37C00 \\
\hline & 2014 & Landsat 8 & LC82211312014005LGN00 \\
\hline
\end{tabular}

See also Extended Data Fig. 7. The year supplied below is the year the melt season in which the evidence for surface drainage is observed, ends. In the majority of cases (for the Landsat imagery) the actual date is contained in the identifier. To avoid repetition, if an image has been displayed in a figure, this is indicated and the identifier can be obtained from Extended Data Table 1. 